\title{
Bromelain: an overview of industrial application and purification strategies
}

\author{
Zatul Iffah Mohd Arshad • Azura Amid • Faridah Yusof • \\ Irwandi Jaswir • Kausar Ahmad • Show Pau Loke
}

Received: 19 March 2014 / Revised: 8 June 2014 / Accepted: 10 June 2014 / Published online: 26 June 2014

(C) Springer-Verlag Berlin Heidelberg 2014

\begin{abstract}
This review highlights the use of bromelain in various applications with up-to-date literature on the purification of bromelain from pineapple fruit and waste such as peel, core, crown, and leaves. Bromelain, a cysteine protease, has been exploited commercially in many applications in the food, beverage, tenderization, cosmetic, pharmaceutical, and textile industries. Researchers worldwide have been directing their interest to purification strategies by applying conventional and modern approaches, such as manipulating the $\mathrm{pH}$, affinity, hydrophobicity, and temperature conditions in accord with the unique properties of bromelain. The amount of downstream processing will depend on its intended application in industries. The breakthrough of recombinant DNA technology has facilitated the large-scale production and purification of recombinant bromelain for novel applications in the future.
\end{abstract}

Keywords Bromelain - Cysteine protease - Purification . Recombinant bromelain

Z. I. M. Arshad · A. Amid $(\bowtie) \cdot$ F. Yusof $\cdot$ I. Jaswir

Bioprocess and Molecular Engineering Research Unit, Department of Biotechnology Engineering, Faculty of Engineering, International Islamic University Malaysia, P.O. Box 10, 50728,

Kuala Lumpur, Malaysia

e-mail: azuraamid@iiium.edu.my

\section{Z. I. M. Arshad}

Faculty of Chemical and Natural Resources Engineering, Universiti Malaysia Pahang, Lebuhraya Tun Razak, 26300 Gambang, Kuantan, Pahang, Malaysia

\section{K. Ahmad}

Kuliyyah of Pharmacy, International Islamic University Malaysia,

P.O. Box 10, 50728 Kuala Lumpur, Malaysia

\section{S. P. Loke}

Manufacturing and Industrial Processes Division, Faculty of Engineering, Centre for Food and Bioproduct Processing, University of Nottingham Malaysia Campus, Jalan Broga, Semenyih, 43500, Selangor Darul Ehsan, Malaysia

\section{Introduction}

Modern technological advancements have raised the protease production industrially worldwide. Today, proteases dominate with approximately $60 \%$ market share of the total enzyme market worldwide where the major producers are Novo Industries, Gist-Brocades, Genencor International, and Miles Laboratories (Feijoo-Siota and Villa 2011). This growth is entrenched with the rising general awareness of the need to protect the environment from the impact of chemical industrialization. Recently, bromelain has drawn attention in diverse industrial applications owing to its properties and higher commercial values (Heinicke and Gortner 1957). Bromelain is a protease derived from the stem and fruit of pineapples (Ananas comosus). Stem bromelain (EC 3.4.22.32), ananain (EC 3.4.22.31), and comosain are extracted from pineapple stems, while fruit bromelain (EC 3.4.22.33) is mainly from fruit juice (Rowan et al. 1990). Similar proteases are also present in pineapple peel, core, crown, and leaves, with the highest proteolytic activity and protein contents detected in the extract of pineapple crown (Ketnawa et al. 2012).

Stem bromelain can be isolated from stem juices by means of precipitation and centrifugation (Devakate et al. 2009; Heinicke and Gortner 1957). Moreover, using chromatographic methods, other basic proteolytic (ananain, comosain, F4, F5, and F9) and acidic components of stem bromelain fraction $\mathrm{A}(\mathrm{SBA} / \mathrm{a})$ and fraction $\mathrm{B}(\mathrm{SBA} / \mathrm{b})$ have been partially and fully purified (Feijoo-Siota and Villa 2011; Harrach et al. 1995, 1998; Murachi et al. 1964; Napper et al. 1994; Rowan et al. 1990; Wharton 1974). The molecular weight of purified stem bromelain is $23.40-35.73 \mathrm{kDa}$, fruit bromelain $31.00 \mathrm{kDa}$, ananain $23.43-23.42 \mathrm{kDa}$, and comosain 23.56 $24.51 \mathrm{kDa}$. The isoelectric point of stem and fruit bromelain is at pH 9.55 and 4.6, respectively (Murachi et al. 1964; Yamada et al. 1976). There is minimal difference in the amino acid composition between stem bromelain, ananain, and comosain 
as shown in Table 1. Stem bromelain contains 285 amino acids where the most abundant amino acids are alanine and glycine, while histidine and methionine are present in the lowest amounts (Murachi 1964; Ota et al. 1964). It appeared to differ significantly in the number of lysine, arginine, and isoleucine compared to ananain and comosain (Napper et al. 1994). Ananain possesses more hydrophobicity in the region near histidine-157 and sequence insert between 170 and 174 residues which cannot be found in stem bromelain (Lee et al. 1997). Stem bromelain also contains four hexosamines, and $2.1 \%$ carbohydrate, meaning it is a glycoprotein (Murachi 1964; Murachi et al. 1964). This observation was corroborated by the findings of Ota et al. (1964), who detected $1.5 \%$ carbohydrate, including six glucosamines, in purified stem bromelain. Later, Murachi et al. (1967) isolated $30 \mathrm{mg}$ of glycopeptides from $1 \mathrm{~g}$ of stem bromelain using gel filtration in an attempt to confirm the presence of a glycoprotein. Murachi et al. (1967) and Yasuda et al. (1970) reported that the carbohydrate composition in stem bromelain consists of mannose, fucose, xylose, and glucosamine in the ratio of 3:1:1:4 using gas chromatography analysis, whereas Scocca and Lee (1969) obtained the same oligosaccharide group with a different ratio of 2:1:1:2 using automated borate chromatography.

Stem bromelain is an endoprotease that breaks peptide bonds within the protein molecule. Stem bromelain is under the papain family which resembles papain unequivocally in the alignment of amino acid sequence. A prominent similarity is observed in their mechanism of action as shown in Fig. 1. Initially, noncovalent bonding involves the free enzyme (structure a) and substrate to form the complex (structure b).

Table 1 Amino acid composition of stem bromelain, ananain, and comosain (Napper et al. 1994)

\begin{tabular}{llll}
\hline Amino acid & Stem bromelain & Ananain & Comosain \\
\hline Asp & 18 & 19 & 18 \\
Thr & 9 & 8 & 7 \\
Ser & 17 & 18 & 17 \\
Glu & 16 & 13 & 13 \\
Gly & 22 & 24 & 25 \\
Ala & 25 & 20 & 20 \\
Val & 14 & 14 & 13 \\
Met & 3 & 2 & 3 \\
IIe & 17 & 14 & 12 \\
Leu & 6 & 9 & 9 \\
Tyr & 14 & 12 & 12 \\
Phe & 6 & 5 & 7 \\
His & 1 & 2 & 2 \\
Lys & 15 & 11 & 10 \\
Arg & 6 & 10 & 11 \\
Cys & 7 & 7 & 7 \\
\hline
\end{tabular}

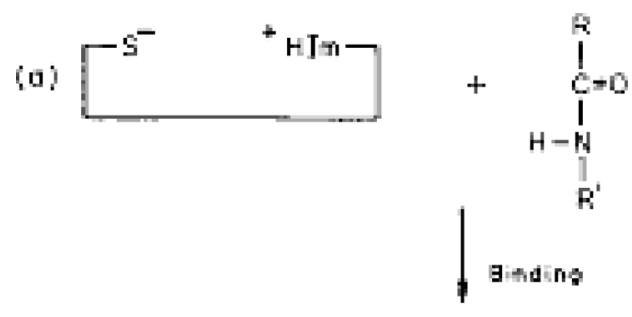

(b)
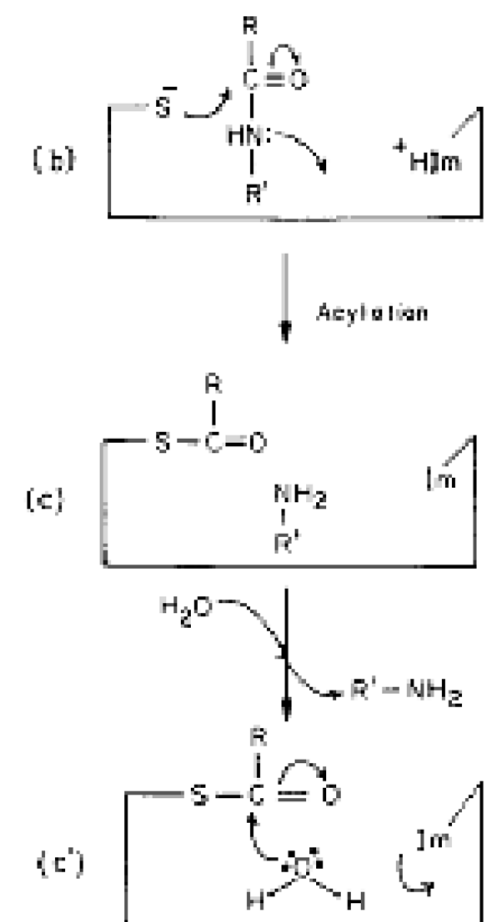

(4)

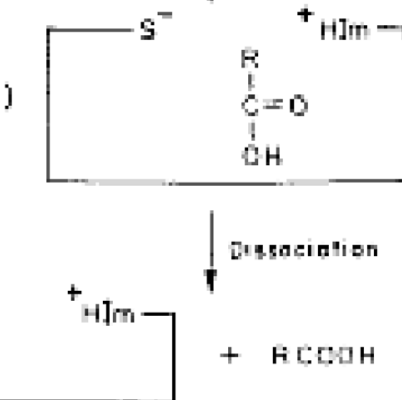

Fig. 1 Catalytic mechanism of cysteine proteinase action. Im and ${ }^{+} \mathrm{HIm}$ referred to imidazole and protonated imidazole (Rao et al. 1998)

Then, the next step is the acylation of the enzyme (structure $\mathrm{c}$ ) which produces amine, with $\mathrm{R}^{\prime}-\mathrm{NH}_{2}$ as the first product. Finally, the deacylation reaction step takes place between the acyl-enzyme and water to release the carboxylic acid, $\mathrm{RCOOH}$, and free enzyme (Rao et al. 1998). The presence of asparagine- 175 hydrogen-bonded with histidine- 159 favors the catalytic function in papain. Stem bromelain is distinguished from papain by its lower value of second-order rate constant of inactivation by iodoacetate and iodoacetamide due 
to the absence of asparagine-175 and two adjacent residues as well as the mutation of serine-176 to lysine in its structure (Ritonja et al. 1989). It is noteworthy that stem bromelain exhibits a weak inhibition by L-3-carboxy-2,3-transepoxypropionyl-leucylamido (4-guanidino) butane (E64) about $678 \mathrm{M}^{-1} \mathrm{~s}^{-1}$ in contrast to papain which is about 638,000 M-1 $\mathrm{s}^{-1}$ (Barrett et al. 1982; Rowan et al. 1990).

Specificity of stem bromelain was markedly examined using different substrates, such as gelatin (gelatin digestion unit), casein (casein digestion unit), azocasein and azoalbumin, hemoglobin, sodium caseinate, Z-Arg-Arg-NHMec, and Z-Arg-Arg- $\rho \mathrm{Na}$ (Corzo et al. 2012; Gautam et al. 2010; Iversen and Jørgensen 1995; Napper et al. 1994; Rowan et al. 1990). Its proteolytic ability efficiently had hydrolyzed glucagon at arginine-alanine and alanine-glutamic acid bonds where it shows preference for glutamic acid, aspartic acid, lysine, or arginine in the $\mathrm{P} 1$ site yet leaves intact the argininearginine and lysine-tyrosine bonds. The release of DNP $(2,4-$ dinitrophenyl)-alanine and DNP-glutamic acid after FDB (fluorodinitrobenzene) treatment becomes an evidence of the successful cleavage at its preference bonds (Murachi and Neurath 1960; Napper et al. 1994). Profiling of substrate specificity for stem bromelain using positional scanning synthetic combinatorial libraries (PS-SCLs) had displayed a cleavage site at arginine (Choe et al. 2006). Generally, stem bromelain is in full activity under the presence of ethylenediaminetetraacetic acid (EDTA) and cysteine, and the addition of mercury (II) chloride $\left(\mathrm{HgCI}_{2}\right)$ causes inhibition of its activity (Murachi and Neurath 1960). The optimum $\mathrm{pH}$ and temperature for stem bromelain activity are in the range of $\mathrm{pH}$ 6.5-8.0 and 55-60 ${ }^{\circ} \mathrm{C}$, respectively, for most of the substrates which are presented in Table 2. Studies of the stability of pineapple fruit in storage without preservative at $-4{ }^{\circ} \mathrm{C}$ indicate that bromelain retains $75 \pm 5 \%$ of its activity, and no microbial growth is detected after 180 days (Bhattacharya and Bhattacharyya 2009). The bromelain degradation profile in aqueous solution at various temperatures follows first-order kinetics, and its activation energy is $41.7 \mathrm{kcal} / \mathrm{mol}$ (Yoshioka et al. 1991).

While the biochemical properties such as molecular weight, optimum $\mathrm{pH}$ and temperature as well as carbohydrate composition in this enzyme display varying degrees of homology from various researchers, judgment on the variation of bromelain resource and purification process has to be scrutinized extensively before awaiting for further industrial development. Thanks to the major breakthrough of modern biotechnology, new analytical technologies to characterize and ensure the safety of the source and end product application have been developed (Staub et al. 2011). Today, escalating growth of commercial manufacturers of stem bromelain (retrieved from http://www.chemicalbook.com) worldwide has swiftly found usage in a wide array of industrial applications such as food, textile, brewing, cosmetic, and dairy products (Polaina and MacCabe 2007). Thus, this review will start with an overview on various applications of bromelain in tenderization, baking industry, protein hydrolysate, enzymatic browning inhibition agent, animal feed, textile industry, tooth whitening as well as cosmetic industry. Next, an in-depth summary on recent purification strategies of bromelain in the last 10 years which include ultrafiltration, precipitation, aqueous two-phase system (ATPS), adsorption, reverse micelle extraction (RME), and chromatography will be provided.

\section{Industrial applications of bromelain}

Bromelain is a plant protease isolated from pineapple. Its strong proteolytic activity has created a wide interest in numerous applications, mainly in tenderization, foods, detergents, and the textile industry. Bromelain has also been envisaged to have extensive applications as an active ingredient in tooth-whitening dentifrices and skin products. In this part of the review, the major applications of bromelain are summarized (see Table 3 ).

Table 2 Optimum $\mathrm{pH}$ and temperature for bromelain with different substrates

\begin{tabular}{lllll}
\hline Type of bromelain & Optimum $\mathrm{pH}$ & Optimum temperature $\left({ }^{\circ} \mathrm{C}\right)$ & Substrates & References \\
\hline Fruit & 6.5 & 55 & Azocasein & Corzo et al. (2012), Bhattacharya \\
& 7.5 & 55 & And Bhattacharyya (2009) \\
& 7.7 & 59 & Casein & \\
& 6.5 & 59 & Sodium caseinate & Ketnawa and Rawdkuen (2011) \\
Peel & 2.9 & 37 & Hemoglobin & Amid et al. (2011) \\
Recombinant & 8 & 60 & Casein & Khan et al. (2003) \\
Stem & 4.6 & 45 & N ${ }^{\alpha}$-CBZ-L-lysine $p$-nitrophenyl ester (LNPE) & Benucci et al. (2011) \\
& 7 & 40 & Casein & Bz-Phe-Val-Arg-pNA
\end{tabular}


Table 3 Industrial applications of bromelain

\begin{tabular}{lll}
\hline Applications & Reasons & References \\
\hline Baking industry & - Improve dough relaxation and allow the dough to rise evenly & Kong et al. (2007), Tanabe et al. (1996), Watanabe et al. (2000) \\
& - Produce hypoallergenic flour & \\
Tenderization & - Hydrolyze meat myofibril proteins & Hage et al. (2012), Sullivan and Calkins (2010), Ketnawa and \\
& - Hydrolyzing agent for meat, oyster, chicken, and squid & Rawdkuen (2011), Chuapoehuk and Raksakulthai (1992) \\
Fish protein & - Hydrolyze fish protein to generate fish protein hydrolysate & Elavarasan et al. (2013), Ren et al. (2008), Tanuja et al. (2012) \\
hydrolysate & Antibrowning agent & - Inhibit browning of fruits and phenol oxidation \\
Alcohol production & - Enhance protein stability of beers & Lozano-De-Gonzalez et al. (1993), Srinath et al. (2012) \\
& - Prevent haze formation & Benucci et al. (2011) \\
Animal feed & - Estimate protein degradation in ruminant feed & Tománková and Kopečný (1995) \\
Textile industry & - Minimize softening time in cocoon cooking & Koh et al. (2006), Devi (2012), Singh et al. (2003) \\
& - Remove scale and impurities of wool and silk fibers & \\
Tooth whitening & - Enhance dyeing properties of protein fibers & \\
Cosmetic industry & - Remove stains, plaque, and food debris on the outer & Chakravarthy and Acharya (2012), Kalyana et al. (2011) \\
& - Treat acne, wrinkles, and dry skin & Ozlen et al. (1995), Levy and Emer (2012)
\end{tabular}

\section{Tenderization}

Tenderness is an important characteristic of meat. The overwhelming demand for guaranteed tender meat has attracted players in the meat industry to provide an acceptable quality of product. In the USA, certified Angus beef was introduced in the late 1970s. Consumers have found it consistently flavorful, juicy, and tender (Koohmaraie and Geesink 2006). Many approaches have been employed to improve postmortem tenderness, including blade tenderization (Pietrasik et al. 2010; Pietrasik and Shand 2011), moisture enhancement technology (Streiter et al. 2012), and enzymatic treatment (Gerelt et al. 2000; Pietrasik and Shand 2011). In a traditional tenderization method, meat is kept cool for up to 10 days to allow postmortem proteolysis by proteolytic enzymes: cathepsins and calpains (Nowak 2011).

The potential of proteolytic enzymes such as bromelain, papain, and ficin has been recognized, as shown by their long history of use in meat tenderization. Compared with papain and ficin, bromelain is commercially available in the market under name brands such as McCormick and Knorr. Commercial papain, bromelain, and zingibain efficiently hydrolyze a few meat myofibril proteins, such as actomysin, titin, and nebulin, as revealed by sodium dodecyl sulfatepolyacrylamide gel electrophoresis (SDS-PAGE) (Hage et al. 2012). Sullivan and Calkins (2010) reported that bromelain can improve the sensory evaluation rating and tenderness of meat comparable to other exogenous enzymes. The addition of bromelain can also produce a tenderizing effect on myosin and other myofibrillar proteins of coarse dry sausage. A number of methods of tenderization using bromelain have been reported. Lizuka and Aishima (1999) successfully applied continuous monitoring using attenuated total reflectance infrared spectroscopy (ATR-IR) to observe the structural changes in meat protein after treatment with pineapple juice. Melendo et al. (1997) studied the effect of $\mathrm{pH}$, temperature, cutting method, and cooking time during marinating with bromelain. Ketnawa and Rawdkuen (2011) demonstrated that treatment of bromelain at up to $20 \%(w / w)$ leads to extensive proteolysis on beef, chicken, and squid. Besides, bromelain can be a good substitute for hydrochloric acid as a hydrolysis agent for oyster meat and, at the same time, receives higher acceptability scores in sensory evaluation in oyster sauce production (Chuapoehuk and Raksakulthai 1992).

\section{Baking industry}

Gluten is a functional component of wheat food products, such as flour. It consists of two major proteins, gliadin and glutenin. Gluten becomes insoluble and forms lattice-like structures when it is hydrated. Therefore, gluten must be degraded to avoid resistance to dough stretching (Walsh 2002). The use of proteolytic enzymes such as bromelain can improve dough relaxation, enhance solubility, and prevent dough shrinkage. This will allow the dough to rise evenly during the baking process (Kong et al. 2007; Polaina and MacCabe 2007). Bromelain also has been used to produce hypoallergenic flour that is suitable for wheat-allergic patients. The immunoglobulin E (IgE)-binding epitope, Gln-Gln-GlnPro-Pro, is a major allergen in flour. Thus, the addition of bromelain can help to hydrolyze peptide bonds near proline (Pro) residues, which degrades the epitope structure (Tanabe et al. 1996; Watanabe et al. 2000). 
Protein hydrolysate

Protein hydrolysate has a long history of use as a nitrogen source for growth media for microbial, plant, and animal cell culture at the laboratory and industrial scales. It is widely used as a nutritional supplement, pharmaceutical ingredient, and flavor enhancer and in cosmetics and beverages. Current practice in the manufacturing of protein hydrolysate involves acid, alkali, and enzyme hydrolysis. However, enzymatic hydrolysis is preferable due to the ease in controlling the degree of hydrolysis as well as shortening the hydrolysis time. The significant parameters for enzymatic hydrolysis are temperature, hydrolysis time, $\mathrm{pH}$, and degree of hydrolysis (DH) (Pasupuleti and Braun 2010). The addition of proteolytic enzymes can make the enzymatic hydrolysis process efficient and reproducible (Chalamaiah et al. 2012). There has been considerable research on the flavor profile (sweet, salty, sour, bitter, bouillon, and umami taste) and functional properties (hypoantigenic, antioxidant, and antimicrobial) of protein hydrolysate isolated from fish and plant sources using commercial bromelain.

Protein hydrolysate derived from food processing byproducts can be used as precursors in the production of meat, savory food, and chicken flavor substitutes. For example, the hydrolysis of mungbean protein by bromelain has released 16 free amino acids which give a meaty flavor characteristic such as bouillon, sweet smell, green, and fatty (Sonklin et al. 2011). Besides, after bromelain hydrolysis, several amino acids such arginine, lysine, and leucine were found from the protein byproduct hydrolysis of Gracilaria fisheri (red seaweeds) which characterize seafood flavoring (Laohakunjit et al. 2014). Sangjindavong et al. (2009) reported on the production of fish sauce from the fermentation of surimi waste accelerated with pineapple core and peel.

In spite of the fact that protein hydrolysate can be used as a flavor agent, the hydrolysis process is often accompanied by bitterness effect due to the reaction of endoprotease with the protein substrate during the hydrolysis. The bitter intensity can be expressed as the taste dilution (TD) factors. Partial hydrolyzation of soy protein isolate (SPI) by bromelain showed lower (TD) factors of 4 and 16 in 10 and $15 \% \mathrm{DH}$, respectively, compared to alcalase and neutrase. This phenomenon could be due to the remaining nonpolar amino acid residues at the $\mathrm{C}$-terminus of the peptide after bromelain hydrolyzes the hydrophobic amino acid residues (Seo et al. 2008). Cheung and Li-Chan (2014) found that after $8 \mathrm{~h}$ of hydrolysis, shrimp hydrolysate by bromelain demonstrated less bitter and high umami taste in the instrumental taste sensing system rather than alcalase and protamex hydrolysate. The bitterness characteristic results from enzymatic hydrolysis and is due to the presence of $\mathrm{N}$-terminal peptide residues which are glycine, leucine, isoleucine, phenylalanine, and valine (Hevia and Olcott 1977).
Recent studies have demonstrated that protein hydrolysates from fish source possess antioxidant activities after enzymatic hydrolysis using various proteolytic enzymes such as bromelain, papain, flavorzyme, protamex, neutrase, and alcalase (Lamsal et al. 2007; Ren et al. 2008; Tanuja et al. 2012). Among these enzymes, bromelain hydrolysate from freshwater carp (Catla catla) is appearing to give high disappearance rates of the free radical 2,2-diphenyl-1-picrylhydrazyl (DPPH) (Elavarasan et al. 2013). Antimicrobial peptides from natural sources can be promising candidates to replace synthetic antimicrobial agents in the treatment of a wide spectrum of bacterial infections. Thus, Ghanbari et al. (2012) explored the application of Actinopyga lecanora (sea cucumber) in the production of antimicrobial peptide. They found that after $7 \mathrm{~h}$ of hydrolysis, hydrolysates prepared by bromelain exhibited the highest antimicrobial activities against Pseudomonas sp., Pseudomonas aeruginosa, and Escherichia coli compared to other hydrolysates generated by papain, alcalase, pepsin, trypsin, and flavorzyme. That study corroborates a previous study performed by Salampessy et al. (2010), which showed the antimicrobial capability of bromelain hydrolysate from leatherjacket (Meuschenia sp.) against Staphylococcus aureus and Bacillus cereus.

Enzymatic browning inhibition agent

The discoloration of fruits into brown color, especially apples and pears, occurs due to the oxidation of phenols to quinones in the presence of oxygen. Further reactions of quinones with other substances, such as phenolic compounds and amino acids, lead to the development of brown pigments. Enzymatic browning may deteriorate the nutritional quality and flavor of the fruits. To control the browning of fresh and canned fruit, ethylene diaminetetraacetic acid (EDTA), ascorbic acid, L-cysteine, citric acid, and phosphoric acid are commonly used (Ozoğlu and Bayındırlı 2002). However, due to health concerns over the side effects caused by chemicalbased enzymatic browning inhibition agents, there has been an increasing amount of research on agents derived from plant-based sources. According to Lozano-De-Gonzalez et al. (1993), eluate from cation exchange of the pineapple juice is effective as a sulfite agent to inhibit browning of fresh and dried apple rings. Later, Srinath et al. (2012) extended that study by partitioning the fruit and crown leaf using cationexchange chromatography after ammonium sulfate precipitation. They concluded that the protease activity and browning inhibition effects were higher in the fruit extract compared to the crown leaf extract. Similarly, Chaisakdanugull et al. (2007) employed pineapple juice that was fractioned by a solid-phase $\mathrm{C}_{18}$ cartridge as an inhibitor of enzymatic browning in bananas. The study reported a $100 \%$ inhibitory effect of bromelain toward polyphenol oxidation (PPO). In contrast to earlier findings, however, stem bromelain had the weakest 
browning inhibition effect compared with commercial L-cysteine and ascorbic acid (Tochi et al. 2009).

\section{Animal feed}

Generally, forages provide $90 \%$ of food energy and nutrients to ruminant animals at low cost. The variation of the nutritional value of forages is highly influenced by the climate, forage species and cultivars, and the preservation method. Therefore, the estimation of soluble nitrogen compounds in rumen is pivotal to assess the forage attributes to maximize its utilization in ruminants diets (Givens et al. 2002). The in sacco (in situ) technique is widely used to analyze the protein degradability of forage. Unfortunately, the technical challenges and lack of standardization limit its practicability (Abdelgadir et al. 2013). The determination of protein degradation in the rumen by the actions of proteases can be an alternative to replace the conventional method, which is highly expensive and time-consuming. The addition of protease to animal feed can increase protein inversion and availability, decrease the cost of animal feed, and increase the source of protein. The use of bromelain in the estimation of protein degradation of cereals, forages, hays, protein concentrates, and silages in ruminants has been successful and produces comparable results with the in sacco method (Polaina and MacCabe 2007; Tománková and Kopečný 1995).

Textile industry

Recently, the use of proteases in the silk industry has expanded enormously, especially the cocoon cooking method. Generally, the cocoon has to be softened by cooking it in the presence of strong alkaline agents and chemicals. However, this conventional technique has a detrimental effect on the quality of the silk thread produced. Thus, the development of an effective cocoon cooking method using enzyme treatment will reduce softening time while increasing production and saving energy. For instance, Singh et al. (2003) reduced the softening time from $20 \mathrm{~h}$ to $30 \mathrm{~min}$ using pineapple extract incorporated with $9.8 \mathrm{mM}$ of sodium carbonate at $60{ }^{\circ} \mathrm{C}$. Additionally, Koh et al. (2006) reported that the pretreatment of silk and wool with bromelain improved tactile behavior and wettability by removing impurities and scale. These effects increased the dye uptake of the wool and silk fibers and at the same time maintained their tensile properties.

Tooth whitening

Tooth discoloration involves their intrinsic color and extrinsic stains on the surface of the teeth. A number of factors that impart extrinsic discoloration include colored foods and beverages such as tea and coffee, tobacco smoking, and tobacco chewing (Watts and Addy 2001). The stigma attached to discolored teeth has raised the demand for tooth-whitening products. Thus, there is heated competition between manufacturers to develop new technologies and oral care products that overcome tooth discoloration. For tooth-whitening and extrinsic stain removal purposes, toothpaste is usually formulated with abrasive agents that whiten teeth by removing plaque, stains, and food debris accumulated on the tooth surface. However, abrasive agents can accelerate tooth wear, and they become ineffective if their particles are too large, as they cannot be captured by toothbrush bristle (Joiner 2010). Therefore, many types of toothpaste containing different enzymes are marketed to remove extrinsic stains (Hannig et al. 2005, 2010). The novel dentifrice efficiency can be accessed through the lightening value. Recently, an in vitro study by Kalyana et al. (2011) reported on the stain removal efficiency of a dentifrice containing papain and bromelain. The proteolytic enzymes disrupted accumulated protein on the tooth surface, which resulted in higher lightening value after brushing compared to the control dentifrice. Chakravarthy and Acharya (2012) corroborated these results, finding that the application of papain and bromelain extracts in dentifrices had a significant lightening effect in comparison with the control dentifrice (Colgate Regular). However, their formulation had the limitation of a shorter shelf life than the usual dentifrice because bromelain and papain are proteolytic in nature.

\section{Cosmetic industry}

The cosmetic products that have papain and bromelain as active ingredients can effectively alleviate skin problems such as wrinkles, acne, and dry skin. These enzymes gently digest the protein of dead cells in the upper layer of the skin, resulting in their replacement by younger skin cells from lower layers (Ozlen and Chatsworth 1995). Bromelain can also reduce bruising and swelling of skin after cosmetic injection treatments (Levy and Emer 2012).

\section{Purification strategies of bromelain}

The continuous interest in bromelain in diverse applications has motivated many researchers to extract the enzyme from pineapple juice and waste and characterize it. The mature pineapple stem contains the highest concentration of bromelain (Heinicke and Gortner 1957). However, pineapple wastes (peel, core, crown, and leaves), which are a by-product in the pineapple processing industry, are also rich in bromelain and are still underutilized. Therefore, Ketnawa et al. (2012), Mutalib et al. (2012), and Nadzirah et al. (2012) investigated the physicochemical properties and proteolytic activity of pineapple waste. The selection of extraction buffer and disruption method is crucial and depends on the target 
protein and its application. The optimal conditions would maximize the extraction efficiency, minimize oxidation, avoid denaturalization, and increase protein acquisition. Ketnawa et al. (2012) investigated the extraction of bromelain from pineapple peels using different extractants. They obtained the highest bromelain activity when it was extracted with $100 \mathrm{mM}$ phosphate buffer with $15 \mathrm{mM}$ cysteine and $2 \mathrm{mM}$ EDTA at $\mathrm{pH}$ 7.0. The addition of a small amount of reducing agent, such as cysteine, and chelating agents, such as EDTA, prevents protein oxidation and traps heavy metals that can boost the oxidation of thiols to inhibit protease action (Chaiwut et al. 2007; Gräslund et al. 2008; Janson 2011). The conventional extraction of bromelain from cooled pineapple juice involves grinding, filtering, and centrifugation. For instance, Shian et al. (2005) and Gautam et al. (2010) employed a homogenization method that disrupts the pineapple stem cells and releases bromelain using sodium acetate solution as an extraction buffer. Later, the crude extracts are filtered and centrifuged to remove cellular debris and insoluble. Once the desired bromelain is free from other particulate residue, the purification continues until a desirable level of purity is achieved, depending on its intended use.

Thorough investigations on the operational design are needed to reduce the cost and number of purification steps in downstream processing. Pre-purification steps such as precipitation, ultrafiltration, and extraction are most commonly employed in the early stage to concentrate and increase the recovery of the target protein. Once a soluble concentrate is obtained, successive purification steps are performed to remove remaining impurities and increase the level of purity. Occasionally, a single pre-purification is enough, but the degree of purification will be low compared to the highresolution steps such as chromatography. Therefore, chromatography steps with ion exchange, affinity, and gel filtration are crucial to provide higher selectivity and purity of the end product. Some novel purification technologies have recently been applied to the purification of bromelain. These include reverse micellar extraction, aqueous two-phase systems, and adsorption. These are currently being employed at a laboratory scale and have yet to be explored in large-scale processing. Here, a brief description of ultrafiltration, precipitation, and chromatography are provided below.

\section{Ultrafiltration}

Ultrafiltration is the best method of concentrating proteins and has been used extensively in the lab and large-scale processes. The ultrafiltration membrane has a molecular weight cutoff ranging from 3 to $100 \mathrm{kDa}$, while microfiltration has a pore diameter ranging from 0.1 to $10 \mu \mathrm{m}$. The retentate containing the protein of interest is retained behind the membrane and is further recycled until the desired concentration is achieved. The permeate is usually discarded as waste (Walsh 2002;
Wheelwright 1991). Doko et al. (1991) have reported on the application of sequential batch filtration, which included microfiltration $(8 \mu \mathrm{m})$ and ultrafiltration (100 kDa cutoff), followed by the additional steps of ammonium precipitation and ultracentrifugation prior to freeze-drying to remove contaminant residues, resulting in $50 \%$ recovery. The recovered product contained $98 \%$ protein. However, the proteolytic activity of bromelain was lost during the protein adsorption onto the ultrafiltration (UF) membranes relative to the level of concentration reached. A similar trend of enzymatic activity was observed when another study applied microfiltration (1.2 and $0.2 \mu \mathrm{m})$ and ultrafiltration $(10 \mathrm{kDa})$ before bioethanol fermentation process (Gimeno et al. 2010). Apparently, the bromelain recovery obtained by Lopes et al. (2009) (90 \%) and Hebbar et al. (2012) (92.4\%) was more than reported by Doko et al. (1991). The additional steps of microfiltration, RME, and ATPS before ultrafiltration caused a significant increase in activity recovery.

\section{Precipitation}

Protein precipitation involves the addition of salts, polar solvents, nonpolar solvents, and organic polymers into cell extracts or by varying the temperature or $\mathrm{pH}$. When the solubility of proteins in solution is reduced by increasing the concentration of precipitating agents, salting out (precipitation) will occur. In a large-scale process (1-5 1 of homogenate), ammonium sulfate is the agent of choice for salting out the proteins because it is effective and relatively cheap. Under saturation (4 $\mathrm{M}$ ammonium sulfate), most protein will precipitate from the solution. Low temperature is favorable to avoid denaturation during precipitation. To recover the protein of interest, additional steps such as centrifugation and dialysis are needed to remove contaminant proteins (Janson 2011). Shian et al. (2005), for example, successfully precipitated 11 of homogenate pineapple juice at $55 \%$ of ammonium sulfate. Partially purified fruit bromelain was also obtained at 30 $80 \%$ saturation by Ko et al. (1996). Similarly, Devakate et al. (2009) described the precipitation of fruit bromelain and achieved 2.81-fold purity at 40-60\% ammonium sulfate saturation. Organic solvents such as ethanol, ketones, methanol, propanol, and other alcohols in protein precipitation have been widely employed.

The addition of organic solvents will decrease the activity of water, as part of the water has been replaced by organic solvents, and cause the proteins to precipitate. Heinicke and Gortner (1957) and Soares et al. (2011) reported the use of acetone and ethanol as the precipitating agents, respectively. Surprisingly, ethanol precipitation yielded 2.07 -fold purification, compared to 4.44 -fold obtained by ammonium precipitation (Soares et al. 2011). Likewise, Soares et al. (2012) only managed to attain a purification factor of 2.28 -fold at 30-70\% ethanol saturation. So far, organic solvent precipitation must 
operate at subzero temperature until the desired concentration $(10-100 \%)$ is achieved to avoid denaturation (Wheelwright 1991). Nonetheless, recently, Silva et al. (2010) improved the quality of stem and rind bromelain recovery and activity in ethanol precipitation with the development of a fedbatch stirred precipitation tank equipped with conventional proportional-integral-derivative (PID) and adaptive PID controllers. They overcame the required temperature increment as a result of heat generated upon the addition of ethanol during precipitation. Organic polymers such as polyethylene glycol (PEG) can precipitate protein and obviate the need for temperature control during the process. Increasing the concentration of PEG increases the amount of precipitated bovine serum albumin (BSA) (Kumar et al. 2009). However, bromelain does not show the same effect as BSA (Soares et al. 2011).

Variations in the temperature, volume of homogenate, mixing conditions, and biochemical properties between fruit and stem bromelain caused the discrepant saturation levels between the above studies. The decrease of repulsive forces and the dominance of attractive forces at the isoelectric point cause protein aggregates to reduce their solubility. Thus, by manipulating the $\mathrm{pH}$, contaminant proteins in the solution can be salted out. Low temperature is favorable in reducing the solubility and precipitating proteins, whereas higher temperature denatures proteins (Walsh 2002; Wheelwright 1991).

\section{Aqueous two-phase system (ATPS)}

ATPS involves the formation of two immiscible phases after the mixing of polymer and salts or the combination of two incompatible polymers (PEG and dextran) in an aqueous solution. The distribution of protein samples between these two phases is influenced by the ionic strength, $\mathrm{pH}$, temperature, molecular weight of the polymer, and type of salt. For instance, under favorable conditions, the target protein tends to partition into the top phase, which is less dense, less polar, and hydrophobic (PEG phase), while contaminant proteins are found in the lower partition, which are more dense, more polar, and hydrophilic (dextran phase) and can be removed through centrifugation (Walsh 2002). A considerable amount of literature has been published on the purification of bromelain using aqueous two-phase systems. Bromelain has been extracted from pineapple fruit by ATPS containing PEGpotassium phosphate (Babu et al. 2008; Hebbar et al. 2012) or PEG-phosphate buffer (Ferreira et al. 2011). Bromelain has also been extracted from pineapple wastes by ATPS. For example, Ketnawa and Rawdkuen (2011) isolated bromelain from pineapple peels using a PEG/magnesium sulfate system, while Coelho et al. (2013) had purified bromelain from stems, barks, and leaves using a PEG/ammonium sulfate system. From all of these studies, it can be concluded that the highest recovery of bromelain is obtained at the highest concentration of PEG and salts applied. This is due to the influence of volume exclusion and the salting out effect, whereby both the bromelain and total protein are in the top PEG-rich phases. However, the partition of bromelain on the top phase decreases as the molecular weight of PEG increases. This is probably due to the structural alteration of enzyme sites in the presence of high molecular weight PEG as well as the fact that bromelain is relatively partitioned in the bottom phase (Babu et al. 2008; Ketnawa et al. 2010). Analogously, thermoseparation of bromelain using an aqueous solution of polyethylene oxide (PEO)-polypropylene oxide (PPO) block copolymers done by Rabelo et al. (2004) had increased the activity recovery by approximately $79.5 \%$, with a purification factor of 1.25 , but the values were relatively lower compared to those of Babu et al. (2008), Ketnawa et al. (2010), and Coelho et al. (2013).

\section{Adsorption}

The adsorption process can be defined as the binding of a dissolved solute to a solid adsorbent. Currently, the use of adsorption with a wide variety of adsorbents is becoming more common in bromelain preparation. For instance, Chen and Huang (2004) applied a magnetic nano-adsorbent using iron oxide nanoparticles as the core and polyacrylic acid (PAA) as the ionic exchange group. Notably, the process successfully produced $87.4 \%$ bromelain activity after adsorption at $\mathrm{pH} 3-5$ and desorption at $\mathrm{pH}$ 7. As bromelain has the property of having a single oligosaccharide chain attached to the polypeptide, Gupta and Saleemuddin (2006) used affinity binding to a Sepharose matrix pre-coupled with the lectin concanavalin A (Con A), which resulted in $60 \%$ bromelain activity at pH 11. Meanwhile, Silveira et al. (2009) integrated the expanded bed adsorption (EBA) to investigate the effect of the expansion degree of Amberlite IRA 410 resin and the residence time distribution, which resulted in 13-fold bromelain purification. Recently, the use of dye ligand affinity membrane chromatography seems more promising because it offers high selectivity, a larger surface area, and excellent thermal and mechanical properties. The electrospun polyacrylonitrile (PAN) nanofibers developed by Zhang et al. (2010) were chemically modified by tethering them to chitosan as a composite bilayer membrane and Cibacron Blue F3GA (CB) as a dye ligand. This successfully captured $161.6 \mathrm{mg} / \mathrm{g}$ of bromelain. Sai-Nan et al. (2009) and Song et al. (2011) employed Reactive Red 120 (Red 120) as a dye ligand immobilized onto chitosan-coated magnetic nanoparticles (CS-MNPs) to achieve bromelain adsorption from aqueous solution. In these studies, $88.2 \%$ activity of bromelain was achieved, and the bromelain adsorption isotherm fits well with the Freundlich model. 
Reverse micelle extraction (RME)

The reverse micelle system is a liquid-liquid extraction technique for biomolecule separation in downstream processing. Reverse micelle systems consist of droplets of aqueous phase separated from an organic solvent by the presence of surfactants in the interface. The surfactants possess both hydrophobic and hydrophilic tails. The polar head (hydrophilic) is located inside the micelle, and the nonpolar tail is in contact with the solvent outside the micelle. The movement of protein inside and outside the micelle can be induced by manipulating the $\mathrm{pH}$, the ionic strength of aqueous phase, and the surfactant concentration (Wheelwright 1991). Several reports on the application of RME for separation and purification of bromelain from pineapple fruit (Yin et al. 2011), juice (Fileti et al. 2009), and wastes (Chaurasiya and Umesh Hebbar 2013; Hebbar et al. 2012; Umesh Hebbar et al. 2008) are available. Yin et al. (2011) and Umesh Hebbar et al. (2008) have demonstrated that the forward extraction efficiency, purification fold, and specific activity of bromelain are optimal at $\mathrm{pH} 7.0$ 8.0. The proteins transfer from the organic solvent to the reverse micelle if the $\mathrm{pH}$ value of the aqueous phase is higher than the isoelectric point of bromelain (4.6). This is because of the electrostatic attraction that occurs when the protein has a positive charge and the internal surface of reverse micelle has a positive charge (cationic surfactant). Chaurasiya and Umesh Hebbar (2013) and Umesh Hebbar et al. (2008) concur that the concentrations of $150 \mathrm{mM}$ cetrimonium bromide (CTAB) and $0.1 \mathrm{M}$ sodium chloride $(\mathrm{NaCl})$ for forward extraction and $0.5 \mathrm{M}$ potassium bromide $(\mathrm{KBr})$ in back extraction produce high-efficiency extraction of bromelain. The protein extraction rates increase when a low ionic strength of salt and a high concentration of surfactant are applied, which in turn favors the forward extraction process. The high concentration of the surfactant increases the stability and number of reverse micelles, while the high ionic strength of salt in the back extraction may reduce the enzymatic exclusion from the interior surface of reverse micelles (Yin et al. 2011). Hebbar et al. (2012) employed the optimized conditions for reverse micelles from Umesh Hebbar et al. (2008) and integrated the system with an ultrafiltration process, resulting in a bromelain activity recovery of $95.8 \%$ and purification fold of 8.9 . Fileti et al. (2009) improved the purification factor to 4.96 by continuous extraction of reverse micelles using a microcolumn with pulsed caps after applying the optimum conditions from the batch operation. Recently, affinity-based reverse micellar extraction and separation (ARMES) has been used to purify bromelain from pineapple core. The authors achieved 12.32 -fold purification with $185.6 \%$ activity recovery, which was higher than those reported by Umesh Hebbar et al. (2008), through the affinity interaction between the bromelain and concanavalin A ligand that been incorporated in the reverse micelle system (Kumar et al. 2011).
Chromatography

Chromatography is a separation method in which protein samples migrate through the column at different rates and conditions of solid stationary and mobile phases. The packed column in chromatography comprises two types of mechanisms: adsorption (e.g., ion exchange, hydrophobic interaction, and affinity) and nonadsorption (e.g., gel filtration) (Wheelwright 1991). Among these methods, ion-exchange chromatography is commonly used to separate bromelain from pineapple fruit, juice and wastes. For example, Murachi and Neurath (1960b) obtained two major components, fractions 2 and 5, which were similar in their activities toward various substrates after ion-exchange fractionation of pineapple juice using Duolite CS101 at $\mathrm{pH}$ 6.05. The purification procedure was improved by Murachi et al. (1964) over the aforementioned method (Murachi and Neurath 1960) through the removal of contaminant carbohydrates and colored material. The latter study successfully produced $0.87 \mathrm{~g}$ of purified bromelain from $10 \mathrm{~g}$ crude commercial bromelain by integrating gel filtration and ammonium sulfate and acetone precipitation steps after ion-exchange purification. Similarly, Yamada et al. (1976) applied ammonium sulfate precipitation after anion-exchange chromatography, which yielded a homogeneous fruit bromelain with a high specific activity of $10 \mathrm{U} / \mathrm{mg}$. Ota et al. (1964) supplemented the observations of Murachi et al. (1964) by further characterizing the extraneous end-group of stem and fruit bromelain after purification by gel filtration and ion-exchange chromatography. Further fractionation by successive use of gel filtration using Sephadex G-75 and ion exchange using carboxymethyl (CM)Sephadex and diethylaminoethyl (DEAE)-Sephacel successfully separated stem bromelain into six proteolytic components (SBA and SBB 1-5) and two active components of fruit bromelain fraction $\mathrm{A}$ (FBA) and $\mathrm{B}$ (FBB) (Ota et al. 1985). Likewise, several studies on stem bromelain purification using cation-exchange and affinity chromatography yielded nonglycosylated components of stem bromelain, referred to as ananain (Napper et al. 1994; Rowan et al. 1990) and F9 (Harrach et al. 1995), as well as the glycosylated components comosain (Napper et al. 1994), F4 and F5 (Harrach et al. 1995), and SBA/a and SBA/b (Harrach et al. 1998). Meanwhile, Ko et al. (1996), Devakate et al. (2009), and Gautam et al. (2010) had employed additional steps of ammonium sulfate precipitation and dialysis prior to ion-exchange chromatography purification to remove most of the impurities in the stem and fruit bromelain samples. A summary of the purification condition of ion-exchange chromatography is presented in Table 4 . 


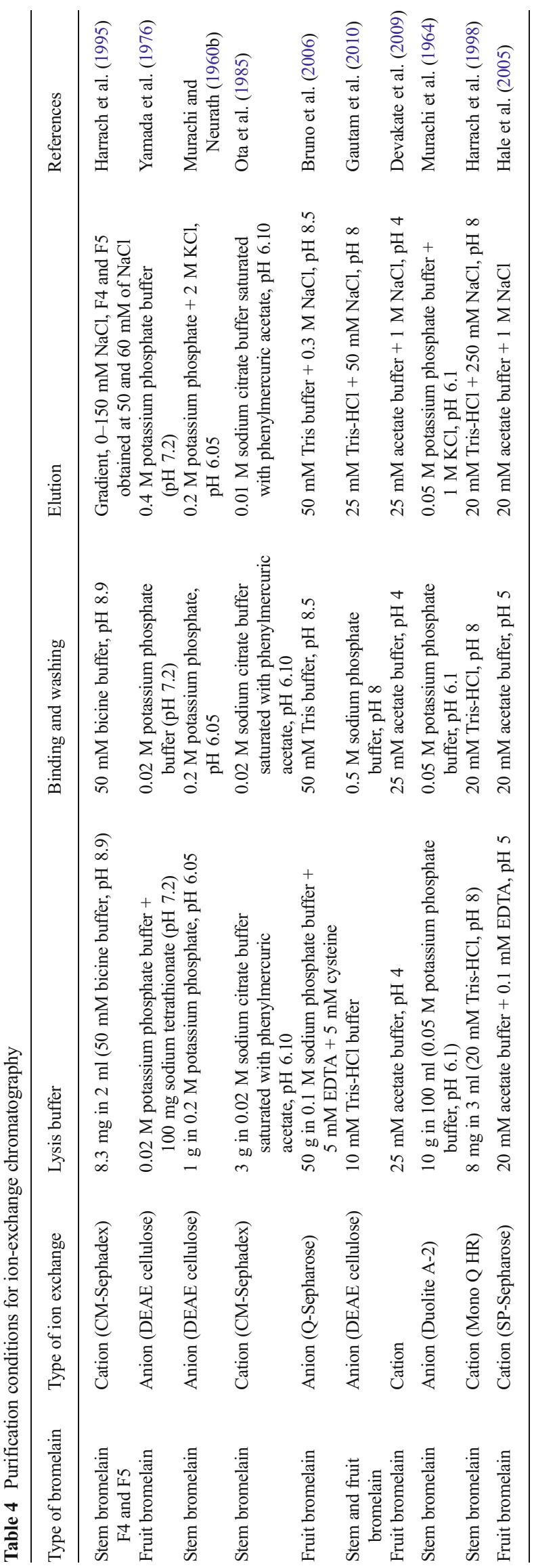

\section{Future directions}

Up to the present, bromelain is a plant protease of choice, owing to its multitude of applications in industries such as tenderization, food, beverage, and pharmaceuticals. However, the utilization of bromelain is still in its infancy due to the rising dispute whether pineapple crops should be designated for growth as food or for bromelain extraction. Additionally, as the main source of bromelain, pineapples carry issues of space required for cultivation, seasonal growth, differences in pharmacological activities, and accessibility of mass production. Therefore, variation in the availability of bromelain sources, such as waste generated from pineapple processing in the form of the crown, peel, stem, and core, is likely to be crucial to fulfill the demand for this enzyme. Separation and isolation of bromelain from pineapple crops are only in the developmental stage, where challenges in technology, purity, and the economic aspects of large-scale production still need to be explored. A full discussion of the pros and cons of all listed purifications is shown in Table 5 .

Thanks to the advent of recombinant technology which exploited E. coli as the workhorse for gene expression systems, the cloned bromelain gene has finally opened up the possibility of tailor-made protein with desirable properties (Amid et al. 2011). Despite the extensive application of protein engineering, there are still research bottlenecks that should be alleviated in the downstream process of recombinant bromelain production. The insertion of a poly-histidine sequence at the $\mathrm{N}$ - or $\mathrm{C}$-terminus of the protein-coding region seems to allow the binding of recombinant bromelain to affinity column that has metal ions attached to it, but such a protein might be susceptible to co-elute with the native $E$. coli proteins, which are referred to as contaminants during the purification process. Therefore, the optimization of purification conditions or re-engineering an $E$. coli strain by mutation or alternative tag addition can be a realistic solution to improve the purity of recombinant bromelain and reduce the number of purification steps. However, in order to avoid unnecessary protein binding to the column, sometimes additional steps such as centrifugation, ultrafiltration, or precipitation are required to remove remaining host cell proteins, polishing, and intensification of the desired protein. The multiple steps in the chromatographic method associated with the huge amount of manufacturing cost needed ultimately will cause a significant drawback in the large-scale downstream process.

Among nonchromatographic methods presented in the aforementioned literature, the aqueous two-phase systems (ATPS) could be promising with the burgeoning interest in bromelain research. This method was adapted successfully in various researches that involve recombinant proteins with a high degree of purity (Bhambure et al. 2013; Lan et al. 2013; Omidinia et al. 2010). This purification method is easy to scale 
Table 5 Comparison of different purification strategies

\begin{tabular}{lll}
\hline Type of purification & Advantages & Disadvantages \\
\hline Ultrafiltration & - Concentrate the protein & $\begin{array}{c}\text { Long separation process } \\
\text { - Increase protein loading will cause the ultrafiltration membrane } \\
\text { clogging }\end{array}$ \\
Precipitation & - Efficient to remove trace contaminants & - Need a dialysis step to remove excess salt during precipitation \\
& - Easy to scale up with simple equipment requirements & \\
Aqueous two phase & - Low energy needed & - Difficult recovery of target protein from phase-forming \\
& - Low cost and shorter separation time & polymer \\
Reverse micelle & - Easy to scale up and produce higher yield & - Efficient to remove trace contaminants \\
System & - Easy to scale up and can be operated in a continuous mode & - Difficult recovery of target protein from surfactant-containing \\
& - No loss of native protein and activity & organic solvent \\
Chromatography & - Low interfacial tension & - Low separation efficiency and higher cost \\
& - Highly specific and scalable & - Small sample loading capacity \\
& & - Multiple chromatography steps
\end{tabular}

up as it only comprises water, salt, and polymer which is a biocompatible environment. With the optimized condition of $\mathrm{pH}$ and composition of salt and polymer, phase separation using centrifugation results in just one-step separation. Nevertheless, few challenges still hampered large-scale ATPS especially in the mechanism of phase separation (interaction between the protein, salt and polymer), reusability and toxicity of the polymer, and mode of operation (batch, semicontinuous, or continuous) (Azevedo et al. 2009). Current research in the manipulation of protein affinity to a biospecific ligand in the phase-forming polymer will favor the selective partitioning of the target protein. Besides, in view of the resolution to overcome drawback in the conventional ATPS system which requires back extraction to recover salt or polymer, the use of thermoseparating polymer could be one promising candidate. The temperature-induced phase partitioning method will offer cost-effectiveness and recyclability to overcome the bulk industrial waste disposal of polymer. Finally, pre-evaluation and detailed cost comparison with other separation methods must be taken into account to determine the viability of the ATPS process in an industrial scale (Espitia-Saloma et al. 2013).

\section{Conclusion}

Bromelain is among the protease enzymes that have been studied extensively. With the development of recombinant bromelain, new applications are expected in the field of pharmaceutical industry. Since the demand for large quantities of pharmaceutical products increases tremendously, the aqueous two-phase system offers high load capacity and easy to scale up for separation process with no compromise in the purity aspects. Modern methods of protein engineering combined with high-throughput approaches such as automatic instrumentation during data collection and analysis are expected to enhance experimental efforts and create systematic methods. Thus, extensive effort involving the cooperation of many experts from various scientific and technological fields should be devoted to identify previously unexplored strategies to characterize recombinant bromelain for novel applications.

\section{References}

Abdelgadir IEO, Cochran RC, Titgemeyer EC, Vanzant ES (2013) In vitro determination of ruminal protein degradability of alfafa and prairie hay via a commercial protease in the presence or absence of cellulase or driselase. J Anim Sci 75:2215-2222

Amid A, Ismail NA, Yusof F, Salleh HM (2011) Expression, purification, and characterization of a recombinant stem bromelain from Ananas comosus. Process Biochem 46(12):2232-2239

Azevedo AM, Rosa PAJ, Ferreira IF, Aires-Barros MR (2009) Chromatography-free recovery of biopharmaceuticals through aqueous two-phase processing. Trends Biotechnol 27(4):240-247. doi: 10.1016/j.tibtech.2009.01.004

Babu BR, Rastogi NK, Raghavarao KSMS (2008) Liquid-liquid extraction of bromelain and polyphenol oxidase using aqueous two-phase system. Chem Eng Process Process Intensif 47(1):83-89. doi:10. 1016/j.cep.2007.08.006

Barrett AJ, Kembhavi AA, Brown MA, Kirschke H, Knight CG, Tamai M, Hanada K (1982) L-trans-Epoxysuccinyl-leucylamido(4guanidino)butane (E-64) and its analogues as inhibitors of cysteine proteinases including cathepsins B, H and L. Biochem J 201(1): 189-198

Benucci I, Liburdi K, Garzillo AMV, Esti M (2011) Bromelain from pineapple stem in alcoholic-acidic buffers for wine application. Food Chem 124(4):1349-1353. doi:10.1016/j.foodchem.2010.07.087

Bhambure R, Sharma R, Gupta D, Rathore AS (2013) A novel aqueous two phase assisted platform for efficient removal of process related impurities associated with E. coli based biotherapeutic protein products. J Chromatogr A. doi:10.1016/j.chroma.2013.07.085 
Bhattacharya R, Bhattacharyya D (2009) Preservation of natural stability of fruit "bromelain" from Ananas comosus (pineapple). J Food Biochem 33(1):1-19

Bruno M, Trejo S, Avilés X, Caffini N, López L (2006) Isolation and characterization of hieronymain II, another peptidase isolated from fruits of Bromelia hieronymi Mez (Bromeliaceae). Protein J 25(3): 224-231

Chaisakdanugull C, Chockchai T, Wrolstad RE (2007) Pineapple juice and its fractions in enzymatic browning inhibition of banana [Musa (AAA group) Gros Michel]. J Agric Food Chem 55:4252-4257

Chaiwut P, Nitsawang S, Shank L, Kanasawud P (2007) A comparative study on properties and proteolytic components of papaya peel and latex proteases. Chiang Mai J Sci 34(1):109-118

Chakravarthy PK, Acharya S (2012) Efficacy of extrinsic stain removal by novel dentifrice containing papain and bromelain extracts. J Young Pharm 4(4):245-249. doi:10.4103/0975-1483.104368

Chalamaiah M, Dinesh Kumar B, Hemalatha R, Jyothirmayi T (2012) Fish protein hydrolysates: proximate composition, amino acid composition, antioxidant activities and applications: a review. Food Chem 135(4):3020-3038. doi:10.1016/j. foodchem.2012.06.100

Chaurasiya RS, Umesh Hebbar H (2013) Extraction of bromelain from pineapple core and purification by RME and precipitation methods. Sep Purif Technol 111(0):90-97. doi:10.1016/j.seppur.2013.03.029

Chen D-H, Huang S-H (2004) Fast separation of bromelain by polyacrylic acid-bound iron oxide magnetic nanoparticles. Process Biochem 39(12):2207-2211. doi:10.1016/j.procbio.2003.11.014

Cheung IWY, Li-Chan ECY (2014) Application of taste sensing system for characterisation of enzymatic hydrolysates from shrimp processing by-products. Food Chem 145(0):1076-1085. doi:10.1016/j. foodchem.2013.09.004

Choe Y, Leonetti F, Greenbaum DC, Lecaille F, Bogyo M, Brömme D, Ellman JA, Craik CS (2006) Substrate profiling of cysteine proteases using a combinatorial peptide library identifies functionally unique specificities. J Biol Chem 281(18):12824-12832. doi:10. 1074/jbc.M513331200

Chuapoehuk P, Raksakulthai N (1992) Use of papain and bromelain in the production of oyster sauce. ASEAN Food J 7(4):196-199

Coelho DF, Silveira E, Pessoa Junior A, Tambourgi EB (2013) Bromelain purification through unconventional aqueous two-phase system (PEG/ammonium sulphate). Bioprocess Biosyst Eng 36(2):185192. doi:10.1007/s00449-012-0774-5

Corzo CA, Waliszewski KN, Welti-Chanes J (2012) Pineapple fruit bromelain affinity to different protein substrates. Food Chem 133(3):631-635. doi:10.1016/j.foodchem.2011.05.119

Devakate RV, Patil VV, Waje SS, Thorat BN (2009) Purification and drying of bromelain. Sep Purif Technol 64(3):259-264

Devi RY (2012) Biotechnological application of proteolytic enzymes in post cocoon technology. Int J Sci Nat 3(2):237-240

Doko MB, Bassani V, Casadebaig J, Cavailles L, Jacob M (1991) Preparation of proteolytic enzyme extracts from Ananas comosus L., Merr. fruit juice using semipermeable membrane, ammonium sulfate extraction, centrifugation and freeze-drying processes. Int $\mathbf{J}$ Pharm 76(3):199-206. doi:10.1016/0378-5173(91)90272-P

Elavarasan K, Naveen Kumar V, Shamasundar BA (2013) Antioxidant and functional properties of fish protein hydrolysates from fresh water carp (Catla catla) as influenced by the nature of enzyme. J Food Process Preserv:n/a-n/a. doi:10.1111/jfpp.12081

Espitia-Saloma E, Vázquez-Villegas P, Aguilar O, Rito-Palomares M (2013) Continuous aqueous two-phase systems devices for the recovery of biological products. Food Bioprod Process. doi:10. 1016/j.fbp.2013.05.006

Feijoo-Siota L, Villa T (2011) Native and biotechnologically engineered plant proteases with industrial applications. Food Bioprocess Technol 4(6):1066-1088
Ferreira JF, Bresolin IRP, Silveira E, Tambourgi EB (2011) Purification of bromelain from Ananas comosus by PEG/phosphate ATPS. Chem Eng Trans 24:931-936

Fileti AMF, Fischer GA, Santana JCC, Tambourgi EB (2009) Batch and continuous extraction of bromelain enzyme by reversed micelles. Braz Arch Biol Techn 52:1225-1234

Gautam SS, Mishra SK, Dash V, Goyal AK, Rath G (2010) Comparative study of extraction, purification and estimation of bromelain from stem and fruit of pineapple plant. Thai J Pharm Sci 34:67-76

Gerelt B, Ikeuchi Y, Suzuki A (2000) Meat tenderization by proteolytic enzymes after osmotic dehydration. Meat Sci 56(3):311-318. doi: 10.1016/S0309-1740(00)00060-7

Ghanbari R, Ebrahimpour A, Hamid AA, Ismail A, Saari N (2012) Actinopyga lecanora hydrolysates as natural antibacterial agents. Int J Mol Sci 13:16796-16811. doi:10.3390/ijms131216796

Gimeno C, Seguí L, Fito P (2010) Valorisation of industrial pineapple residues: bromelain separation followed by bioethanol fermentation. In: Int Conf Food Innov Food Innova 2010, p 1-4

Givens DI, Owen E, Axford RFE, Omed HM (2002) Forage evaluation in ruminant nutrition. CABI Publishing

Gräslund S, Nordlund P, Weigelt J, Hallberg BM, Bray J, Gileadi O, Knapp S, Oppermann U, Arrowsmith C, Hui R, Ming J, dhePaganon S, Park H-w, Savchenko A, Yee A, Edwards A, Vincentelli R, Cambillau C, Kim R, Kim S-H, Rao Z, Shi Y, Terwilliger TC, Kim C-Y, Hung L-W, Waldo GS, Peleg Y, Albeck S, Unger T, Dym O, Prilusky J, Sussman JL, Stevens RC, Lesley SA, Wilson IA, Joachimiak A, Collart F, Dementieva I, Donnelly MI, Eschenfeldt WH, Kim Y, Stols L, Wu R, Zhou M, Burley SK, Emtage JS, Sauder JM, Thompson D, Bain K, Luz J, Gheyi T, Zhang F, Atwell S, Almo SC, Bonanno JB, Fiser A, Swaminathan S, William F, Studier, Chance MR, Sali A, Acton TB, Xiao R, Zhao L, Ma LC, Hunt JF, Tong L, Cunningham K, Inouye M, Anderson S, Janjua H, Shastry R, Ho CK, Wang D, Wang H, Jiang M, Montelione GT, Stuart DI, Owens RJ, Daenke S, Schütz A, Heinemann U, Yokoyama S, Büssow K, Gunsalus KC (2008) Protein production and purification. Nat Meth 5(2):135-146

Gupta P, Saleemuddin M (2006) Bioaffinity based oriented immobilization of stem bromelain. Biotechnol Lett 28(12):917-922

Hage DS, Anguizola JA, Bi C, Li R, Matsuda R, Papastavros E, Pfaunmiller E, Vargas J, Zheng X (2012) Pharmaceutical and biomedical applications of affinity chromatography: recent trends and developments. J Pharm Biomed Anal:1-13

Hale LP, Greer PK, Trinh CT, James CL (2005) Proteinase activity and stability of natural bromelain preparations. Int Immunopharmacol 5(4):783-793

Hannig C, Hannig M, Attin T (2005) Enzymes in the acquired enamel pellicle. Eur J Oral Sci 113(1):2-13. doi:10.1111/j.1600-0722.2004. 00180.x

Hannig C, Spitzmüller B, Lux HC, Altenburger M, Al-Ahmad A, Hannig M (2010) Efficacy of enzymatic toothpastes for immobilisation of protective enzymes in the in situ pellicle. Arch Oral Biol 55(7):463469. doi:10.1016/j.archoralbio.2010.03.020

Harrach T, Eckert K, Schulze-Forster K, Nuck R, Grunow D, Maurer HR (1995) Isolation and partial characterization of basic proteinases from stem bromelain. J Protein Chem 14(1):41-52. doi:10.1007/ bf01902843

Harrach T, Eckert K, Maurer HR, Machleidt I, Machleidt W, Nuck R (1998) Isolation and characterization of two forms of an acidic bromelain stem proteinase. J Protein Chem 17(4):351-361. doi:10. 1023/a:1022507316434

Hebbar U, Sumana B, Hemavathi AB, Raghavarao KSMS (2012) Separation and purification of bromelain by reverse micellar extraction coupled ultrafiltration and comparative studies with other methods. Food Bioprocess Tech 5(3):1010-1018. doi:10.1007/ s11947-010-0395-4 
Heinicke R, Gortner W (1957) Stem bromelain - a new protease preparation from pineapple plants. Econ Bot 11(3):225-234

Hevia P, Olcott HS (1977) Flavor of enzyme-solubilized fish protein concentrate fractions. J Agric Food Chem 25(4):772-775. doi:10. 1021/jf60212a044

Iversen SL, Jørgensen MH (1995) Azocasein assay for alkaline protease in complex fermentation broth. Biotechnol Tech 9(8):573-576. doi: $10.1007 / \mathrm{bf00152446}$

Janson J-C (2011) Protein purification: principles, high resolution methods, and applications, 3rd edition. John Wiley \& Sons

Joiner A (2010) Whitening toothpastes: a review of the literature. J Dent 38:e17-e24

Kalyana P, Shashidhar A, Meghashyam B, SreeVidya KR, Sweta S (2011) Stain removal efficacy of a novel dentifrice containing papain and bromelain extracts - an in vitro study. Int J Dent Hyg 9(3): 229-233. doi:10.1111/j.1601-5037.2010.00473.x

Ketnawa S, Rawdkuen S (2011) Application of bromelain extract for muscle foods tenderization. Food Nutr Sci 2:393-401. doi:10.4236/ fns. 2011.25055

Ketnawa S, Rawdkuen S, Chaiwut P (2010) Two phase partitioning and collagen hydrolysis of bromelain from pineapple peel Nang Lae cultivar. Biochem Eng J 52(2-3):205-211. doi:10.1016/j.bej.2010. 08.012

Ketnawa S, Chaiwut P, Rawdkuen S (2012) Pineapple wastes: a potential source for bromelain extraction. Food Bioprod Process 90(3):385391

Khan R, Rasheedi S, Haq S (2003) Effect of pH, temperature and alcohols on the stability of glycosylated and deglycosylated stem bromelain. J Biosci 28(6):709-714. doi:10.1007/bf02708431

Ko B-S, Hwang Y-I, Lee S-C (1996) Simple purification of bromelain from pineapple. J Food Sci Nutr 1(1):106-110

Koh J, Kang S-M, Kim S-J, Cha M-K, Kwon Y-J (2006) Effect of pineapple protease on the characteristics of protein fibers. Fibers Polym 7(2):180-185. doi:10.1007/bf02908264

Kong X, Zhou H, Qian H (2007) Enzymatic hydrolysis of wheat gluten by proteases and properties of the resulting hydrolysates. Food Chem 102(3):759-763. doi:10.1016/j.foodchem.2006.06.062

Koohmaraie M, Geesink GH (2006) Contribution of postmortem muscle biochemistry to the delivery of consistent meat quality with particular focus on the calpain system. Meat Sci 74(1):34-43. doi:10. 1016/j.meatsci.2006.04.025

Kumar V, Sharma VK, Kalonia DS (2009) Effect of polyols on polyethylene glycol (PEG)-induced precipitation of proteins: impact on solubility, stability and conformation. Int J Pharm 366(1-2):38-43. doi:10.1016/j.ijpharm.2008.08.037

Kumar S, Hemavathi AB, Hebbar HU (2011) Affinity based reverse micellar extraction and purification of bromelain from pineapple (Ananas comosus L. Merryl) waste. Process Biochem 46(5):12161220. doi:10.1016/j.procbio.2011.02.008

Lamsal BP, Jung S, Johnson LA (2007) Rheological properties of soy protein hydrolysates obtained from limited enzymatic hydrolysis. LWT - Food SciTechnol 40(7):1215-1223. doi:10.1016/j.lwt.2006. 08.021

Lan JC-W, Yeh C-Y, Wang C-C, Yang Y-H, Wu H-S (2013) Partition separation and characterization of the polyhydroxyalkanoates synthase produced from recombinant Escherichia coli using an aqueous two-phase system. J Biosci Bioeng 116(4):499-505. doi:10.1016/j. jbiosc.2013.04.010

Laohakunjit N, Selamassakul O, Kerdchoechuen O (2014) Seafood-like flavour obtained from the enzymatic hydrolysis of the protein byproducts of seaweed (Gracilaria sp.). Food Chem. doi:10.1016/j. foodchem.2014.02.101

Lee KL, Albee KL, Bernasconi RJ, Edmunds T (1997) Complete amino acid sequence of ananain and a comparison with stem bromelain and other plant cysteine proteases. Biochem J 327: 199-202
Levy LL, Emer JJ (2012) Complications of minimally invasive cosmetic procedures: prevention and management. J Cutan Aesthet Surg 5(2): 121-132. doi:10.4103/0974-2077.99451

Lizuka K, Aishima T (1999) Tenderization of beef with pineapple juice monitored by fourier transform infrared spectroscopy and chemometric analysis. J Food Sci 64(6):973-977. doi:10.1111/j.13652621.1999.tb12262.x

Lopes FLG, Severo Júnior JB, Souza RR, Ehrhardt DD, Santana JCC, Tambourgi EB (2009) Concentration by membrane separation processes of a medicinal product obtained from pineapple pulp. Braz Arch Biol Technol 52:457-464

Lozano-De-Gonzalez PG, Barrett DM, Wrolstad RE, Durst RW (1993) Enzymatic browning inhibited in fresh and dried apple rings by pineapple juice. J Food Sci 58(2):399-404

Melendo JA, Beltrán JA, Roncalés P (1997) Tenderization of squid (Loligo vulgaris and Illex coindetii) with bromelain and a bovine spleen lysosomal-enriched extract. Food Res Int 30(5):335-341. doi:10.1016/s0963-9969(97)00057-4

Murachi T (1964) Amino acid composition of stem bromelain*. Biochem 3(7):932-934. doi:10.1021/bi00895a014

Murachi T, Neurath H (1960) Fractionation and specificity studies on stem bromelain. J Biol Chem 235(1):99-107

Murachi T, Yasui M, Yasuda Y (1964) Purification and physical characterization of stem bromelain*. Biochem 3(1):48-55

Murachi T, Suzuki A, Takahashi N (1967) Evidence for glycoprotein nature of stem bromelain. Isolation of a glycopeptide*. Biochem 6(12):3730-3736. doi:10.1021/bi00864a015

Mutalib SRA, Samicho Z, Abdullah N, Zaman NK, Hajar N Effect of maturity of pineapple variety $\mathrm{N} 36$ on its waste physico-chemical properties. In: 2012 I.E. Colloq Hum Sci Eng Res 3-4 Dec. 2012 2012. p 432-436

Nadzirah KZ, Zainal S, Noriham A, Normah I, Roha AMS (2012) Physico-chemical properties of pineapple crown extract variety N36 and bromelain activity in different forms. APCBEE Procedia 4(0):130-134. doi:10.1016/j.apcbee.2012.11.022

Napper AD, Bennett SP, Borowski M, Holdridge MB, Leonard MJ, Rogers EE, Duan Y, Laursen RA, Reinhold B, Shames SL (1994) Purification and characterization of multiple forms of the pineapplestem-derived cysteine proteinases ananain and comosain. Biochem J 301:727-735

Nowak D (2011) Enzymes in tenderization of meat - the system of calpains and other systems - a review. Pol J Food and Nutr Sci 61(4):231-237. doi:10.2478/v10222-011-0025-5

Omidinia E, Shahbaz Mohamadi H, Dinarvand R, Taherkhani H-A (2010) Investigation of chromatography and polymer/salt aqueous two-phase processes for downstream processing development of recombinant phenylalanine dehydrogenase. Bioprocess and Biosyst Eng 33(3):317-329. doi:10.1007/ s00449-009-0327-8

Ota S, Moore S, Stein WH (1964) Preparation and chemical properties of purified stem and fruit bromelains*. Biochem 3(2):180-185. doi:10. 1021/bi00890a007

Ota S, Muta E, Katahira Y, Okamoto Y (1985) Reinvestigation of fractionation and some properties of the proteolytically active components of stem and fruit bromelains. J Biochem 98(1): 219-228

Ozlen SN, Chatsworth C (1995) Cosmetic composition containing alpha hydroxyacids, salicyclic acid, and enzyme mixture of bromelain and papain. United States Patent 5:441,740

Ozoğlu H, Bayındırlı A (2002) Inhibition of enzymic browning in cloudy apple juice with selected antibrowning agents. Food Control 13(4 5):213-221. doi:10.1016/S0956-7135(02)00011-7

Pasupuleti VK, Braun S (2010) State of the art manufacturing of protein hydrolysates. In: Demain AL, Pasupuleti VK (eds) Protein hydrolysates in biotechnology. Springer, Netherlands, pp 11-32 
Pietrasik Z, Shand PJ (2011) Effects of moisture enhancement, enzyme treatment, and blade tenderization on the processing characteristics and tenderness of beef semimembranosus steaks. Meat Sci 88(1):813. doi:10.1016/j.meatsci.2010.11.024

Pietrasik Z, Aalhus JL, Gibson LL, Shand PJ (2010) Influence of blade tenderization, moisture enhancement and pancreatin enzyme treatment on the processing characteristics and tenderness of beef semitendinosus muscle. Meat Sci 84(3):512-517

Polaina J, MacCabe AP (2007) Industrial enzymes: structure, function and applications. Springer, Netherland

Rabelo APB, Tambourgi EB, Pessoa A Jr (2004) Bromelain partitioning in two-phase aqueous systems containing PEO-PPO-PEO block copolymers. J Chromatogr, B 807(1):61-68. doi:10.1016/j.jchromb. 2004.03.029

Rao MB, Tanksale AM, Ghatge MS, Deshpande VV (1998) Molecular and biotechnological aspects of microbial proteases. Microbiology and Molecular Biology Reviews 62(3):597-635

Ren J, Zhao M, Shi J, Wang J, Jiang Y, Cui C, Kakuda Y, Xue SJ (2008) Purification and identification of antioxidant peptides from grass carp muscle hydrolysates by consecutive chromatography and electrospray ionization-mass spectrometry. Food Chem 108(2): 727-736. doi:10.1016/j.foodchem.2007.11.010

Ritonja A, Rowan AD, Buttle DJ, Rawlings ND, Turk V, Barrett AJ (1989) Stem bromelain: amino acid sequence and implications for weak binding of cystatin. FEBS Lett 247(2):419-424. doi:10.1016/ 0014-5793(89)81383-3

Rowan AD, Buttlet DJ, Barrett AJ (1990) The cysteine proteinases of the pineapple plant. Biochem J 266:869-875

Sai-Nan S, Yu-Ting Z, Hua-Li N, Li-Min Z, Branford-White CJ (2009) Isotherm, Kinetic and thermodynamic analysis of bromelain adsorption on reactive blue 4 immobilized composite membranes. In: 3rd Int Conf Bioinf Biomed Eng ICBBE 2009 11-13 June 2009 p 1-4

Salampessy J, Phillips M, Seneweera S, Kailasapathy K (2010) Release of antimicrobial peptides through bromelain hydrolysis of leatherjacket (Meuchenia sp.) insoluble proteins. Food Chem 120(2):556-560. doi:10.1016/j.foodchem.2009.10.054

Sangjindavong M, Mookdasanit J, Wilaipun P, Chuapoehuk P, Akkanvanitch C (2009) Using pineapple to produce fish sauce from surimi waste. Kasetsart J (Nat Sci) 43:791-795

Scocca J, Lee YC (1969) The composition and structure of the carbohydrate of pineapple stem bromelain. J Biol Chem 244(18):4852-4863

Seo WH, Lee HG, Baek HH (2008) Evaluation of bitterness in enzymatic hydrolysates of soy protein isolate by taste dilution analysis. J Food Sci 73(1):41-46. doi:10.1111/j.1750-3841.2007.00610.x

Shian MLP, Baharil NAS, Yu TL, Taher M, Majid FAA Pilot scale extraction of proteolytic enzyme bromelain from pineapple (Ananas comosus). In: 2nd Int Conf Chem Bioprocess Eng in conjunction with (SOMChE 2005), Kota Kinabalu, Sabah., 2005

Silva FVD, Santos RLA, Fujiki TL, Leite MS, Fileti AMF (2010) Design of automatic control system for the precipitation of bromelain from the extract of pineapple wastes. Food Sci Technol (Campinas) 30: $1033-1040$

Silveira E, Souza-Jr ME, Santana JCC, Chaves AC, Porto ALF, Tambourgi EB (2009) Expanded bed adsorption of bromelain (E.C.3.4.22.33) from Ananas comosus crude extract. Braz J Chem Eng 26(01):149-157

Singh LR, Devi YR, Devi SK (2003) Enzymological characterization of pineapple extract for potential application in oak tasar (Antheraea proylei J.) silk cocoon cooking and reeling. Electron J Biotechnol 6(3):198-207

Soares PAG, Coelho D, Mazzola P, Silveira E, Carneiro-da-Cunha MG, Pessoa AJ, Tambourgi E (2011) Studies on bromelain precipitation by ethanol, poly (ethylene glycol) and ammonium sulphate. Chem Eng Trans 24(5):979-984. doi:10.3303/CET1124164
Soares PAG, Vaz AFM, Correia MTS, Pessoa A Jr, Carneiro-da-Cunha MG (2012) Purification of bromelain from pineapple wastes by ethanol precipitation. Sep Purif Technol 98:389-395. doi:10.1016/ j.seppur.2012.06.042

Song M-M, Nie H-L, Zhou Y-T, Zhu L-M, Bao J-Y (2011) Affinity adsorption of bromelain on Reactive Red 120 immobilized magnetic composite particles. Sep Sci Technol 46(3):473-482. doi:10.1080/ 01496395.2010.517594

Sonklin C, Laohakunjit N, Kerdchoechuen O (2011) Physicochemical and flavor characteristics of flavoring agent from mungbean protein hydrolyzed by bromelain. J Agric Food Chem 59(15):8475-8483. doi:10.1021/jf202006a

Srinath R, Ramalingam C, Nasimun Islam N (2012) Isolation and characterization of bromelain from pineapple (Ananas comosus) and comparing its anti-browning activity on apple juice with commercial antibrowning agents. Elixir Food Sci 45:7822-7826

Staub A, Guillarme D, Schappler J, Veuthey J-L, Rudaz S (2011) Intact protein analysis in the biopharmaceutical field. J Pharm Biomed Anal 55(4):810-822. doi:10.1016/j.jpba.2011.01.031

Streiter PJ, Campbell CP, Mandell IB (2012) The effects of skeletal separation and moisture enhancement for improving the eating quality of cull cow beef. Meat Sci 92(4):400-408. doi:10.1016/j. meatsci.2012.05.002

Sullivan GA, Calkins CR (2010) Application of exogenous enzymes to beef muscle of high and low-connective tissue. Meat Sci 85(4):730 734. doi:10.1016/j.meatsci.2010.03.033

Tanabe S, Arai S, Watanabe M (1996) Modification of wheat flour with bromelain and baking hypoallergenic bread with added ingredients. Biosci, Biotechnol, Biochem 60(8):1269-1272

Tanuja S, Viji P, Zynudheen AA, Joshy CG (2012) Composition, functional properties and antioxidative activity of hydrolysates prepared from the frame meat of Striped catfish (Pangasianodon hypophthalmus). Egypt J Biol 14:27-35

Tochi BN, Wang Z, Xu SY, Zhang W (2009) Effect of stem bromelain on the browning of apple juice. Am J Food Technol:1-8

Tománková O, Kopečný J (1995) Prediction of feed protein degradation in the rumen with bromelain. Anim Feed Sci Technol 53(1):71-80. doi:10.1016/0377-8401(94)00735-R

Umesh Hebbar H, Sumana B, Raghavarao KSMS, Umesh Hebbar H, Sumana B, Raghavarao KSMS (2008) Use of reverse micellar systems for the extraction and purification of bromelain from pineapple wastes. Bioresour Technol 99:4896-4902. doi:10.1016/j. biortech.2007.09.038

Walsh G (2002) Proteins: biochemistry and biotechnology. John Wiley \& Sons Ltd, England

Watanabe M, Watanabe J, Sonoyama K, Tanabe S (2000) Novel method for producing hypoallergenic wheat flour by enzymatic fragmentation of the constituent allergens and its application to food processing. Biosci, Biotechnol, Biochem 64(12):2663-2667

Watts A, Addy M (2001) Tooth discolouration and staining: tooth discolouration and staining: a review of the literature. Br Dent $\mathrm{J}$ 190(6):309-316. doi:10.1038/sj.bdj.4800959

Wharton CW (1974) The structure and mechanism of stem bromelain. Biochem J 143:575-586

Wheelwright SM (1991) Protein purification. Design and scale up of downstream processing. John Wiley \& Sons, Inc

Yamada F, Takahashi N, Murachi T (1976) Purification and characterization of a proteinase from pineapple fruit, fruit bromelain FA2. J Biochem 79(6):1223-1234

Yasuda Y, Takahashi N, Murachi T (1970) Composition and structure of carbohydrate moiety of stem bromelain. Biochem 9(1):25-32. doi: 10.1021/bi00803a004

Yin L, Sun CK, Han X, Xu L, Xu Y, Qi Y, Peng J (2011) Preparative purification of bromelain (EC 3.4.22.33) from pineapple fruit by high-speed counter-current chromatography using a reverse-micelle 
solvent system. Food Chem 129(3):925-932. doi:10.1016/j. foodchem.2011.05.048

Yoshioka S, Izutsu K-i, Aso Y, Takeda Y (1991) Inactivation kinetics of enzyme pharmaceuticals in aqueous solution. Pharm Res 8(4):480484. doi:10.1023/a:1015899011324
Zhang $\mathrm{H}$, Nie $\mathrm{H}, \mathrm{Yu} \mathrm{D}$, Wu C, Zhang Y, White CJB, Zhu L (2010) Surface modification of electrospun polyacrylonitrile nanofiber towards developing an affinity membrane for bromelain adsorption. Desalin 256(1-3):141-147. doi:10.1016/j. desal.2010.01.026 